\title{
Head characteristics and acceptability of cabbage cultivars grown in southern Puerto Rico'
}

\author{
Guillermo Fornaris-Rullán, Isabel Beauchamp de Caloni \\ and Lucas Aviléz-Rodríguez ${ }^{2}$
}

\begin{abstract}
Ten cabbage (Brassica oleracea l., var. capitata) cultivars were evaluated in terms of head characteristics and consumer acceptability. They were planted at the Fortuna agricultural experiment substation, on the southern coast of Puerto Rico. Head weight ranged from $1.73 \mathrm{~kg}$ to $0.61 \mathrm{~kg}$; diameter from $17.55 \mathrm{~cm}$ to $12.40 \mathrm{~cm}$; and head length from 16.28 $\mathrm{cm}$ to $13.79 \mathrm{~cm}$. No significant difference was observed in head weight among cultivars Río Verde (with the highest score), Bravo and Big Cropper; nor between Titanic and Market Prize. Río Verde had the largest diameter. There were no significant differences in diameter between cultivars Rio Verde and Big Cropper; nor among Big Cropper, Bravo, Titanic, Market Prize and Superette. Río Verde scored the highest in appearance. Appearance of other cabbage cultivars was not significantly different. All cultivars scored high in terms of flavor, texture and general acceptability by the taste panel, both raw and cooked. In general terms, Río Verde, Bravo, Titanic, Market Prize and Big Cropper scored the highest.
\end{abstract}

\section{RESUMEN}

\section{Características y aceptabilidad de variedades de repollo cultividades en el sur de Puerto Rico}

Se evaluaron 10 cultivares de repollo (Brassica oleracea L. var. capitata) en cuanto a características de aceptabilidad. Las cultivares se sembraron en la subestación experimental agrícola de Fortuna, en la costa sur de Puerto Rico. El peso de las cabezas fluctuó de $1.73 \mathrm{~kg}$. a $0.61 \mathrm{~kg}$; diámetro de $17.55 \mathrm{~cm}$. a $12.40 \mathrm{~cm}$.; y el largo, de $16.28 \mathrm{~cm}$. a $13.79 \mathrm{~cm}$. No hubo diferencias significativas en peso entre las cultivares Río Verde (el valor más alto), Bravo y Big Cropper ni entre Titanic y Market Prize. En cuanto al diámetro, Río Verde fuvo el valor más alto. No hubo diferencias significativas en diámetro entre las cultivares Río Verde y Big Cropper ni entre Big Cropper, Bravo, Titanic, Market Prize y Superette. Río Verde fue la de mejor en apariencia. Las demás cultivares no fueron significativamente diferentes en apariencia. Todas las cultivares obtuvieron una buena evaluación en términos de sabor, textura y aceptabilidad general cuando las muestras se sometieron a una cata crudas o cocidas. En términos generales, las que recibieron las puntuaciones más altas fueron Río Verde, Bravo, Titanic y Big Cropper.

'Manuscript submitted to Editorial Board 2 May 1989.

"Assistant Researcher-Horticulture, Food Technologist-Food Technology Laboratory and Assistant Researcher-Horticulture, respectively, Agricultural Experiment Station, University of Puerto Rico Mayagüez Campus, Rio Piedras, Puerto Rico. 


\section{INTRODUCTION}

Cabbage Brassica oleracea L. var. capitata is an important vegetable crop, especially in temperate regions. World production peaked in 1979 with an estimated 33.5 million $t$ in approximately 1.6 million ha (9). In Puerto Rico, it is also considered as a major vegetable crop, but only $40 \%$ of the cabbage consumed was locally grown in 1983-84 (7).

Fresh succulent vegetable crops such as cabbage are always recommended for good nutrition. Cabbage is an excellent source of vitamin C, potassium and dietary fiber (1). Although some vitamin $\mathrm{C}$ is lost during cooking, still frequent consumption of cabbage is encouraged for its low caloric value and high vitamin content.

As part of our efforts to increase local cabbage production, 10 cabbage cultivars were evaluated during the 1984-85 growing season as to head characteristics and product acceptability with respect to appearance, flavor and texture. These are among the quality components considered of importance to producers, receivers, market distributors and consumers $(4,6,8)$.

In Puerto Rico, most of the cabbage is grown in the municipalities of Orocovis and Barranquitas, in the mountain area (7). The potential for increased production, however, is in the coastal flat lands of the southern region, where operations can be easily mechanized, climate is favorable and irrigation is available.

\section{MATERIALS AND METHODS}

Seedlings of cabbage cultivars (Green Express, Big Cropper, Sun Up, Bravo, Market Prize, Superette, Titanic, Copenhagen Market 126, Dessert 126 and Río Verde) were transplanted 4 December 1984 at the Fortuna Agricultural Experiment Substation, located on the semiarid southern coast of Puerto Rico.

The plants were grown in a San Antón soil (Mollisols; Cumulic Haplustolls; fine-loamy, mixed, isohyperthermic) occurring on nearly level alluvial fans (3). Table 1 shows temperatures and rainfall during the experimental cycle.

All cultivars were grown according to the technical practices recommended by the Agricultural Experiment Station (2). After transplanting, the experiment was irrigated twice a week for the first 2 weeks and thereafter once a week or when necessary. Dacthal W- $75^{3}$ was used as a preemergent herbicide immediately after transplanting. Hand weeding followed as required. To control foliage insects and diseases, we sprayed

\footnotetext{
3Trade names are used in this publication solely for the purpose of providing specific information. Mention of trade names does not constitute a guarantee, warranty, or endorsement by the Agricultural Experiment Station indicating superiority to other similar products not mentioned.
} 
TABLE 1.-Climatic conditions prevailing at Fortunu Substation during the experimental cycle

\begin{tabular}{lcccc}
\hline & \multicolumn{3}{c}{ Average daily temperature } & \\
\cline { 2 - 4 } Month & $\max$ & $\min$ & mean & Rainfall \\
\hline & ${ }^{\circ} \mathrm{C}$ & ${ }^{\circ} \mathrm{C}$ & ${ }^{\circ} \mathrm{C}$ & $\mathrm{mm}$ \\
November/84 & 30.3 & 20.2 & 25.2 & 280.5 \\
December/84 & 29.5 & 18.3 & 23.9 & 15.9 \\
January/85 & 29.5 & 17.1 & 23.3 & 3.9 \\
February/85 & 29.9 & 18.5 & 24.2 & 38.5 \\
\hline
\end{tabular}

the plants weekly with Diazinon AG-500, Lannate 90-S or Monitor 4-E, mixed with Dithane M-45 X or Kocide 101.

A partially balanced incomplete block design with four replications was used. Each plot was $6.10 \times 3.66 \mathrm{~m}$ with 4 rows $0.91 \mathrm{~m}$ apart and 13 plants per row, $0.46 \mathrm{~m}$ apart. The weight of every harvested head was recorded and its diameter and length were measured. For many years, Market Prize was considered by local growers as the standard cabbage cultivar. However, because of its commercial performance during the past two years, Rio Verde might be considered as the new standard cultivar for Puerto Rico.

Cabbage head samples, after being stored in a cold room at $10^{\circ} \mathrm{C}$ for approximately 30 days, were submitted to sensory evaluation by a trained taste panel. We evaluated both raw and cooked cabbage, using the $+2,-2$, scale for general acceptability. Quality attributes of appearance, flavor, texture and overall acceptability were evaluated by means of a 6-point hedonic scale. Cultivars were also ranked as to appearance (5).

Following local market preferences, we included in the sensory evaluations no cultivar with an average head weight less than $1.00 \mathrm{~kg}$ or an average head diameter smaller than $13.00 \mathrm{~cm}$. Because of differences among cultivars for first harvest date, they were evaluated in groups. Head samples from either first or second harvest were used in order to have as many cultivars as possible in each group.

\section{RESULTS AND DISCUSSION}

Table 2 shows days to first harvest and average head characteristics for the 10 cabbage cultivars. Head weight ranged from $1.73 \mathrm{~kg}$ for Río Verde to $0.61 \mathrm{~kg}$ for Dessert 126. Río Verde, Big Cropper and Bravo were not significantly different in head weight. They were followed by Titanic and Market Prize. The largest head diameters were for Rio Verde $(17.55 \mathrm{~cm})$ and Big Cropper $(16.55 \mathrm{~cm})$. No significant differences were observed between Big Cropper, Bravo, Titanic, Market Prize and Superette. With respect to head length, there were no significant differ- 
TABLE 2.-Harvesting date and head characteristics of cabbage cultivars evaluated during the 1984-85 trial

\begin{tabular}{lcccc}
\hline Cultivar & Days to first harvest' & Head weight & Head diameter & Head length \\
\hline & & $k g$ & $\mathrm{~cm}$ & $\mathrm{~cm}$ \\
Rio Verde & 83 & $1.73 \mathrm{a}^{2}$ & $17.55 \mathrm{a}$ & $15.00 \mathrm{ab}$ \\
Big Cropper & 78 & $1.68 \mathrm{a}$ & $16.55 \mathrm{ab}$ & $14.60 \mathrm{~b}$ \\
Bravo & 78 & $1.64 \mathrm{a}$ & $15.34 \mathrm{~b}$ & $15.13 \mathrm{ab}$ \\
Titanic & 78 & $1.39 \mathrm{~b}$ & $15.44 \mathrm{~b}$ & $16.28 \mathrm{a}$ \\
Market Prize & 69 & $1.39 \mathrm{~b}$ & $15.09 \mathrm{bc}$ & $14.22 \mathrm{c}$ \\
Superette & 69 & $1.21 \mathrm{c}$ & $14.93 \mathrm{bc}$ & $15.09 \mathrm{ab}$ \\
Green Express & 62 & $1.04 \mathrm{~d}$ & $13.50 \mathrm{~cd}$ & $15.11 \mathrm{ab}$ \\
Copenhagen Market 86 & 62 & $0.78 \mathrm{e}$ & $12.65 \mathrm{~d}$ & $15.80 \mathrm{ab}$ \\
Sun Up & 69 & $0.72 \mathrm{ef}$ & $12.83 \mathrm{~d}$ & $14.45 \mathrm{~b}$ \\
Dessert 126 & 62 & $0.61 \mathrm{f}$ & $12.40 \mathrm{~d}$ & $13.79 \mathrm{c}$ \\
\hline
\end{tabular}

${ }^{1}$ Days to harvest from transplant date (12-04-84).

'Means in the same column followed by a letter in common do not differ significantly at the $5 \%$ probability level by $T$ test.

ences among Titanic, which showed the highest value $(16.28 \mathrm{~cm})$, and Río Verde, Bravo, Superette, Green Express and Copenhagen Market 86.

Table 3 presents results of the sensory analysis for the raw cabbage cultivars in terms of appearance. Scores represent the sum of ranks per cultivar for each group. No significant differences in appearance were found among samples evaluated in the first group. Río Verde was superior at the 5\% probability level, both in the second and third groups. No significant difference was observed among other cultivars evaluated.

Table 4 presents the results of the organoleptic evaluation of raw cabbage evaluations. A significant difference was observed only in the second group, between Superette (lowest value) and the other cultivars. Green Express was rated best in acceptability in the first group, Market

TABLE 3.-Appearance evaluation of raw cabbage cultivars by group.

\begin{tabular}{lccc}
\hline & \multicolumn{3}{c}{ Appearance sum of ranks' } \\
\cline { 2 - 4 } Cultivar & First group & Second group & Third group \\
\hline Green Express & 17 & & \\
Market Prize & 14 & $21 \mathrm{~b}^{2}$ & \\
Superette & 17 & $24 \mathrm{~b}$ & $28 \mathrm{~b}$ \\
Titanic & & $31 \mathrm{~b}$ & $12 \mathrm{a}$ \\
Rio Verde & & $14 \mathrm{a}$ & $22 \mathrm{~b}$ \\
Bravo & & $30 \mathrm{~b}$ & $18 \mathrm{~b}$ \\
Big Cropper & & & \\
\hline
\end{tabular}

'Scored based on Rank Totals - Inferior - Superior.

${ }^{2}$ Ranks in the same column followed by the same letter do not differ significantly at the $5 \%$ probability level by $T$ test. 
TABLE 4.-Flavor evaluation of raw cabbage cultivars by group

\begin{tabular}{lccc} 
& \multicolumn{3}{c}{ Flavor mean values $^{1}$} \\
\cline { 2 - 4 } Cultivar & First group & Second group & Third group \\
\hline Green Express & 1.43 & & \\
Market Prize & 1.00 & $1.56 \mathrm{a}^{2}$ & \\
Superette & 1.14 & $0.89 \mathrm{~b}$ & \\
Titanic & & $1.44 \mathrm{a}$ & 1.17 \\
Rio Verde & & $1.56 \mathrm{a}$ & 1.38 \\
Bravo & & $1.44 \mathrm{a}$ & 1.67 \\
Big Cropper & & 1.13 \\
\hline
\end{tabular}

$1+2,-2$ scale were $+2=$ very acceptable, $+1=$ acceptable, $0=$ questionable, $-1=$ slightly unacceptable, $-2=$ not acceptable.

${ }^{2}$ Means in the same column followed by the same letter do not differ significantly at the $5 \%$ probability level by $T$ test.

Prize and Río Verde, in the second group, and Río Verde and Bravo in the third group.

Table 5 shows results of the sensory evaluation of the cooked cabbage cultivars. All cultivars were highly acceptable in appearance and flavor when cooked except Superette which was rated "acceptable" in appearance and "moderately acceptable" in flavor. No significant difference was observed for appearance and flavor among cultivars in the three groups. No significant differences were observed as to texture and overall acceptability. Titanic and Bravo received the highest rating for overall accept-

TABLE 5.-Sensory evaluation of cooked cabbage cultivars by group

\begin{tabular}{lcccc}
\hline & \multicolumn{3}{c}{ Mean Values' } \\
\cline { 2 - 5 } Cultivar & Appearance & Flavor & Texture & Overall acceptability \\
\hline$\quad$ First Group & & & & \\
Green Express & 5.44 & 4.89 & 4.78 & 4.89 \\
Market Prize & 5.33 & 4.67 & 4.89 & 4.89 \\
Superette & 5.56 & 4.78 & 4.89 & 4.78 \\
$\quad$ & & & & \\
$\quad$ Second group & 5.37 & 5.00 & 4.50 & 4.50 \\
Market Prize & 5.25 & 5.13 & 5.25 & 5.25 \\
Titanic & 5.38 & 5.00 & 4.50 & 4.38 \\
Río Verde & 4.75 & 4.38 & 4.88 & 4.88 \\
Superette & 5.13 & 5.25 & 5.50 & 5.38 \\
Bravo & & & & \\
$\quad$ Third group & 5.67 & 4.89 & 5.00 & 4.89 \\
Bravo & 5.40 & 5.20 & 5.10 & 5.10 \\
Río Verde & 5.11 & 5.22 & 5.33 & 5.00 \\
Titanic & 5.10 & 5.10 & 5.10 & 5.20 \\
Big Cropper & &
\end{tabular}

' 6 point hedonic scale; $6=$ like very much; $1=$ do not like. 
TABLE 6.-Sensory evaluation of cooked cabbage cultivars

\begin{tabular}{lcccc}
\hline & \multicolumn{4}{c}{ Mean values' } \\
\cline { 2 - 5 } Cultivar & Appearance & Flavor & Texture & Overall acceptability" \\
\hline Green Express & 5.44 & 4.89 & 4.78 & 4.89 \\
Market Prize & 5.35 & 4.82 & 4.71 & 4.71 \\
Superette & 5.18 & 4.59 & 4.88 & 4.83 \\
Titanic & 5.18 & 5.18 & 5.29 & 5.12 \\
Rí Verde & 5.39 & 5.11 & 4.83 & 4.78 \\
Bravo & 5.41 & 5.06 & 5.23 & 5.12 \\
Big Cropper & 5.10 & 5.10 & 5.10 & 5.20 \\
\hline
\end{tabular}

16 point hedonic scale were $6=$ like very much; $1=$ do not like.

${ }^{2}$ Values greater than 4.00 are considered accoptable.

ability in the second group; Río Verde, Titanic and Big Cropper in the third group.

Table 6 shows results of the sensory evaluation mean values of all cooked cabbage cultivars, independently of the group in which they were evaluated. Appearance was highly acceptable for all cultivars. Green Express, Bravo, Río Verde and Market Prize scored the highest. Titanic, Rio Verde, Big Cropper and Bravo scored the highest acceptability in terms of flavor. Titanic, Bravo and Big Cropper were preferred by the panelists as to texture and overall acceptability. No significant difference in appearance, flavor, texture and overall acceptability was found among cultivars.

Table 6 shows results of the sensory evaluation mean values of all cooked cabbage cultivars, independently of the group in which they were evaluated. Appearance was highly acceptable for all cultivars. Green Express, Bravo, Rio Verde and Market Prize scored the highest. Titanic, Río Verde, Big Cropper and bravo scored the highest acceptability in terms or flavor. Titanic, Bravo and Big Cropper were preferred by the panelists as to texture and overall acceptability. No significant difference in appearance, flavor, texture and overall acceptability was found among: cultivars.

\section{LITERATURE CITED}

1. Agricultural Research Service, USDA, 1975. Nutrive value of American foods in common units. Agric. Hand. 456, D.C.

2. Estación Experimental Agrícola, 1979. Conjunto tecnológico para la producción de hortalizas. Univ. P. R., Agric. Exp. Stn. Publ. 102. 2nd ed, p. 54-55.

3. Gierbolini, R. E., 1979. Soil survey of the Ponce area of southern Puerto Rico. USDA Soil Conservation Serv., in cooperation with Univ. P. R., College Agric. Sci.

4. Kader, A. A., 1985. Quality factors: definition and evaluation for fresh harticultural crops, p. 118-21. In: Kader, A. A., R. F. Kasmire, F. G. Mitchell, M. S. Reid, N. F. Sommer and J. F. Thompson. Postharvest Technology of Horticultural Crops. Univ. Calif., Div. of Agric. \& Nat. Resources, Special Publ. 3311. 
5. Larmond, E., 1977. Laboratory Methods for Sensory Evaluation of Food. Canada Dep. Agric., Research Branch. Publ. 1637.

6. Maynard, D., 1985. Selection of vegetable varieties for use in Florida. Univ. Florida, IFAS. Vegetarian Nwsl. (85-5). p. 7-8.

7. Medrano-Vaquero, H., 1985. Situación económica, empresa de hortalizas, p. 72-79. In: Agric. Ext. Serv. Las Empresas Agricolas de Puerto Rico: Situación y Perspectiva. Univ. P. R., Col. Agric, Dep. Econ. Agric. y Sociología Rural.

8. Thompson, H. C. and W. C. Kelly, 1957. Vegetable Crops. McGraw-Hill Co. p. 78-79.

9. Yamaguchi, M., 1983. World vegetables - principles, production and nutritive values. AVI Publ. Co., Westport, CT. 